\title{
Precipitation extremes in the changing climate of Europe
}

\author{
Zbigniew W. Kundzewicz ${ }^{1,2, *}$, Maciej Radziejewski ${ }^{1,3}$, Iwona Pińskwar ${ }^{1}$ \\ ${ }^{1}$ Research Centre for Agricultural and Forest Environment, Polish Academy of Sciences, Bukowska 19, 60809 Poznań, Poland \\ ${ }^{2}$ Potsdam Institute for Climate Impact Research, Telegrafenberg, 14412 Potsdam, Germany \\ ${ }^{3}$ Faculty of Mathematics and Computer Science, Adam Mickiewicz University, Umultowska 87, 61-614 Poznán, Poland
}

\begin{abstract}
Several episodes of extreme precipitation or extreme lack of precipitation (and high temperature) leading to dramatic and high-impact floods and droughts have occurred in Europe in recent years. Climate scenarios suggest that problems of too little or too much water may become more severe in the future. Using data from the Hadley Centre's HadRM3 model, this paper analyzes future changes in the characteristics of intense precipitation (mean daily precipitation amounts and number of days with intense precipitation in a year) and the duration of dry (also dry and hot) spells over the European continent, comparing the time periods of 1961-1990 and 2070-2099. The potential for intense precipitation is likely to increase in the warmer climate of the future, contributing to the growth of flood hazard in areas where inundations are typically triggered by heavy rain. The projected number of days with intense precipitation and the maximum daily precipitation are likely to increase over much of Europe, especially in the central and northern parts. According to projections, 'dry and hot' extremes may become more severe for most of Europe. The areas already affected by water stress in the present climate (e.g. southern Europe) are expected to experience even more severe conditions.
\end{abstract}

KEY WORDS: Precipitation $\cdot$ Intense precipitation $\cdot$ Floods $\cdot$ Droughts $\cdot$ Climate projections

\section{INTRODUCTION}

A considerable increase in flood damage has been observed worldwide in the last decades. In many recent flood events the material losses exceeded US\$ 1 billion (up to US\$ 30 billion material damage during the summer 1998 floods in China), while in some events in less-developed countries the number of flood fatalities has been $>1000$. Most flood fatalities occur outside Europe, in particular in Asia (e.g. China, India, Bangladesh), but in the last decade floods have severely affected large parts of the European continent (cf. Kundzewicz et al. in press).

For example, Poland suffered dramatic summer floods in 1997 (the event in the Odra basin also caused considerable damage in the Czech Republic and Germany), 1998, and 2001. The year 2002 was particularly marked by destructive floods in Europe. It is estimated that the material flood damage recorded in the European continent in 2002 was higher than in any single year before. According to data from the risk insurance firm Munich $\mathrm{Re}$, the material flood damage in central Europe (Czech Republic, Germany, Austria) along the Danube and Labe/Elbe rivers and their tributaries exceeded $€ 15$ billion in August 2002 alone. Not long after, in September 2002, people were killed during severe storms and floods in southern France (Rhone valley) and total material losses exceeded US $\$ 1$ billion.

At times, much of Europe, especially the south, suffers pronounced summer droughts of high intensity, duration and areal coverage, typically related to blocking anticyclonic synoptic conditions and persistent high pressure. Heat waves and lack of precipitation lead to considerable water stress, driving potential evapotranspiration. The August 2003 drought is known to have caused widespread damage in much of Europe. 
According to assessments of Munich Re, economic losses of the hot summer in 2003 exceeded US\$ 18 billion, with drought accounting for one-third of this figure.

Climate change scenarios suggest that such natural disasters resulting from precipitation extremes may become more severe in the future.

\section{METHODOLOGY}

The present study analyzes changes in 2 kinds of precipitation extremes - intense precipitation and long dry (or dry and hot) spells - based on results of climate model simulations. The results from the Hadley Centre Regional Climate Model (HadRM3-P), with spatial resolution 0.44 by $0.44^{\circ}$, are used in the analysis for the whole European region.

In a model verification study, T. Holt et al. (unpubl.) compared extremes in climate models with NCEP (National Center for Environmental Prediction) reanalysis data over the control period 1961-1990. The ambient climatology of the models and reanalysis were compared using a high-resolution monthly dataset (CRU TS 2.0), derived solely from station observations. The aim of T. Holt et al.'s (unpubl.) study was to identify areas where there is marked divergence between the model and NCEP indices of extremes. Examination of the different fields indicates that, apart from areas they identified, there is generally quite good agreement between NCEP and the models for most indices over much of the MICE domain. Zolina et al. (2004) compared statistical characteristics of daily precipitation from different reanalyses with each other and with station data over Europe, and found that the interannual variability of statistical characteristics in different reanalyses is quite consistent over northern and eastern Europe.

This study used runs of the HadRM3-P model for 2 scenarios from the Special Report on Emissions Scenarios (SRES), A2 and B2 (Nakicenovic et al. 2000). Results presented in the figures of this study refer to the SRES A2 scenario, which corresponds to a heterogeneous world with a continually increasing global population and regionally oriented, fragmented and slow economic growth. The daily precipitation totals (P) and maximum daily temperature $\left(\mathrm{T}_{\max }\right)$ data from the HadRM3-P simulations over the European continent were compared for two $30 \mathrm{yr}$ periods (1961-1990 and 2070-2099). Significance of changes in these indices was assessed using Student's $t$-test. Analyses of extremes, reported in the present study, were carried out both on the continental European scale and on a local scale. Some local results are also shown to illustrate the regional-model grid cell embracing the town of Poznań (Wielkopolska Province, Poland, located in a lowland landscape with negligible orographic effect), which is of particular interest to the authors (who live and work there), their institutions, and to regional stakeholders involved.

The MICE partners agreed on the selection of indices of extremes that were of particular interest to impact sectors. The annual indices included in this study were

- Maximum P

- Distribution of P (percentiles)

- Number of days when precipitation exceeds threshold values (10 or $20 \mathrm{~mm}$ )

- Duration of the longest 'dry and hot' spell in summer (i.e. the number of consecutive days with maximum temperature $\geq 25$ or $30^{\circ} \mathrm{C}$, with $\mathrm{P} \leq 0,0.1$, or $0.5 \mathrm{~mm}$ )

- Duration of the longest 'dry' spell in summer (i.e. the number of consecutive days when $\mathrm{P} \leq 0,0.1$, or $0.5 \mathrm{~mm}$ ) in summer.

Some cells along the border of the studied range (as in the data provided) are in the boundary relaxation zone. However, the optically-distinguishable differences in the marginal cells should not lead to confusion in figures presented in the present study.

\section{INTENSE PRECIPITATION}

In Europe, trends in observed annual and seasonal precipitation (New et al. 1999, McCarthy et al. 2001) differ between northern and southern parts of the continent. Over the 20th century, the mean annual precipitation has increased in northern Europe and has decreased in southern Europe (New et al. 1999). Pronounced increase in autumn and winter precipitation in the latter part of the 20th century has been observed over northern Europe and western Russia. Regional precipitation scenarios developed in the framework of the 'A Concerted Action for Climate Impact Assessment' (ACACIA) project (Parry 2000) show a marked contrast between future winter and summer precipitation change in Europe. Wetter winters are predicted throughout the continent, with the 2 regions of highest increase being the NE and NW Mediterranean coasts. In summer, a strong difference in precipitation change between northern Europe (getting wetter) and southern Europe (getting drier) is predicted. The extremes of precipitation are likely to be impacted more than the mean in the future. As the water holding capacity of the atmosphere, and thus its absolute potential water content, increases with temperature, the possibility of intense precipitation also increases.

There are a number of studies in which increases of intense precipitation in observed records were documented (for data over whole years, or for some seasons). Klein Tank \& Koennen (2003) found that Europe- 
average indices of precipitation extremes increased, even though the spatial trends were not coherent. The spatial inhomogeneity of the trend patterns is largely influenced by the orography and subgrid-scale processes. During the 20th century, a clear increasing trend in intensity of winter and autumn heavy precipitation in Switzerland was observed, whereas heavy precipitation did not show statistically significant trends in spring and summer (Frei \& Schär 2001, Schmidli \& Frei 2005). Brunetti et al. (2004) concluded that the Italian climate became warmer and drier over the 20th century. A reduction in the number of wet days was observed, accompanied by an increase in precipitation intensity-i.e. an increasing trend in both heavy precipitation and long dry spells. Alpert et al. (2002) reported a paradoxical increase in extreme rainfall in spite of a decrease in precipitation totals in Italy and Spain. Osborn \& Hulme (2002) found that for 1961-2000 data in UK, intensity of precipitation has increased in winter and decreased in summer. However, in some regional studies in Europe, no significant trend in extreme rainfall intensity was found (e.g. Graczyk \& Kundzewicz 2002).

It was found in the MICE Project that, based on results of climate models, intense precipitation may become more intense and more frequent in the warming world. This agrees with the general projection of 'more intense precipitation events (very likely, over many areas)' in the 21st century (McCarthy et al. 2001). Results obtained from the MICE Project for the European region show that even if (according to HadRM3-P results) mean summer precipitation over much of Europe is likely to decrease from the control period (1961-1990) to the period of interest in the 21st century (2070-2099; Fig. 1), this is not necessarily so for the highest quantiles of $\mathrm{P}$ amounts or for annual maximum P (Fig. 2), which are likely to increase over many areas. This result is in agreement with the findings of Christensen \& Christensen (2003), who used another climate model. Fig. 3 represents the results of a comparison of the number of days with are likely to intense precipitation exceeding an arbitrarily selected threshold. It shows the difference between the number of days with $\mathrm{P}>10 \mathrm{~mm}$ simulated by HadRM3-P for the control and projected periods (1961-1990 and 2070-2099). The map shows a projected reduction in the number of days with intense precipitation along the northern Mediterranean and an increase over northern Europe.

Increase in intense precipitation leads to an increase of flood hazard in areas where inundations are typically triggered by intense summer rain (cf. Kundzewicz et al. in press). Also, during wetter and warmer winters, with increasingly more frequent rain and less frequent snow, flood hazard may increase. On the other hand, because of the marked warming that is projected, ice-jam floods are likely to become less frequent and less severe over much of Europe. Since snowmelt is earlier and less abundant, the risk of spring floods decreases.

Flood hazard tends to increase over many areas, due to a range of climatic and non-climatic impacts whose relative importance is site-specific. Apart from changes in the climatic system (discussed above), changes affecting flood hazard have also occurred in economic and social systems, and in terrestrial systems (hydrological systems and ecosystems). Land-use changes, which induce land-cover changes, control the rainfallrunoff relations. Deforestation, urbanization, and reduction of wetlands diminish the available water storage capacity and increase the runoff coefficient, leading to growth in the flow amplitude and reduction of the time-to-peak of a flood triggered by 'typical' intense precipitation. However, the degree of intensity of a 'typical' intense precipitation event has also been increasing as the climate warms.

Furthermore, human encroachment into unsafe areas has increased the potential for damage. Societies become more exposed, developing flood-prone areas

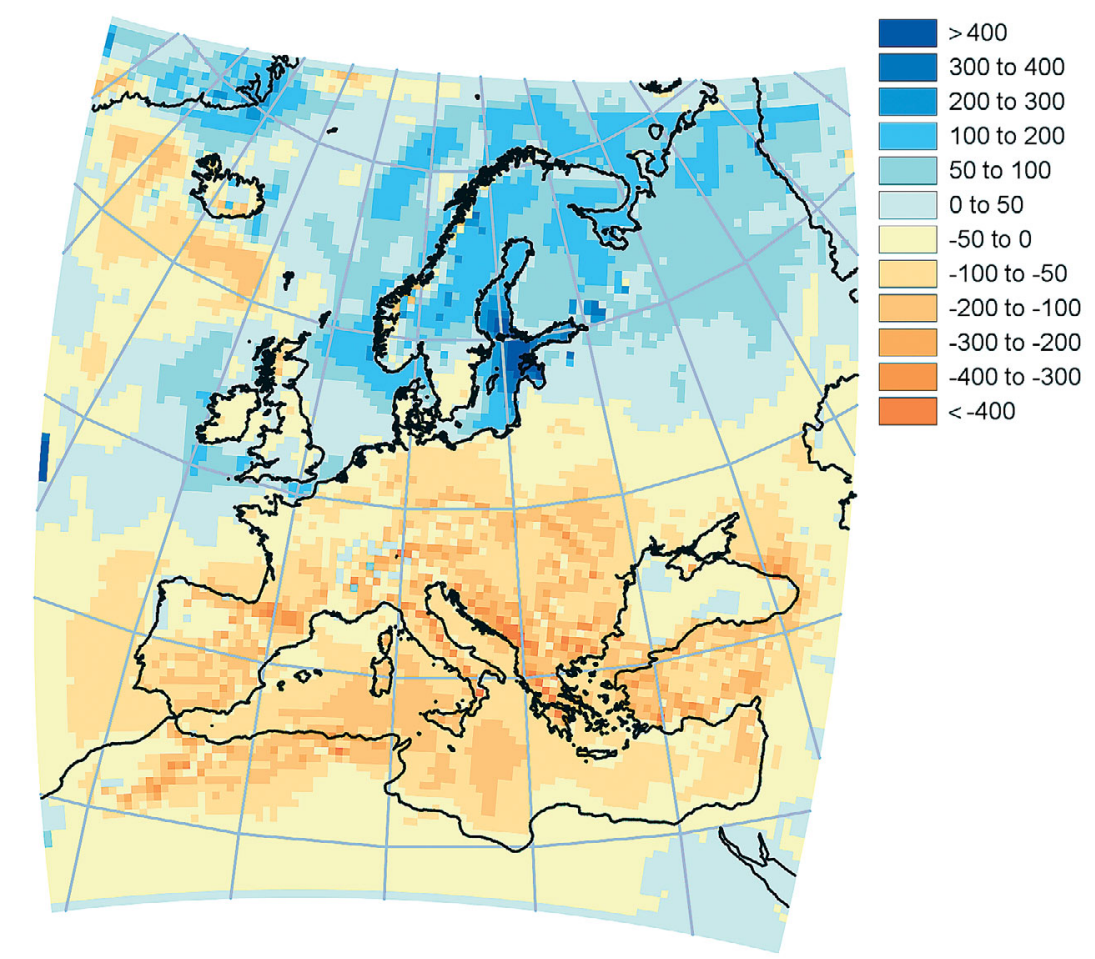

Fig. 1. Difference in mean precipitation (annual values, $\mathrm{mm}$ ) over Europe between the control period (1961-1990) and future projection (2070-2099) (HadRM3-P, SRES A2 scenario) 
(maladaptation). However, even an oversized and perfectly-maintained dike does not guarantee complete protection, as it may not withstand an extreme flood (much higher than the design flood). When a dike is overtopped or when it breaks, the damage in the inundated areas is likely to be higher than it would have been in a levee-free situation. According to Pielke \& Downton (2000), climate has played an important, but by no means determining, role in the growth of damaging floods in the United States in recent decades. The increasing flood damage was found to be largely associated with increasing human development of flood plains (a consequence of population growth and burgeoning national wealth), with a much smaller effect from increased precipitation (Pielke \& Downton 2000).

As stated by Arnell \& Liu (2001), changes in future flood frequency in Europe are complex and depend on the generating mechanism, e.g. increasing flood magnitudes when floods result from heavy precipitation, or decreasing magnitudes when spring floods are generated by snowmelt. Climate change is likely to cause an increase in the risk of riverine flooding across much of Europe.

\section{SUMMER DROUGHT}

Even though a statistically significant increase in global land precipitation over the 20th century was observed, there are areas where precipitation has decreased. For instance, mean annual precipitation in some parts of southern Europe has decreased by as much as $20 \%$ over the 20th century (New et al. 1999). As summarized by McCarthy et al. (2001), projected changes in extreme climate events in the 21st century show likely increased summer drying in continental interiors. Hence the recent severe droughts can be seen as an indication of what may happen in the warmer future.

The projections obtained within the MICE Project show that 'dry and hot' extremes may become more severe in the future climate for most of Europe. The present study used results from HadRM3-P simulations and was restricted to the summer period (June, July, August), for which changes in 'dry extremes' and 'dry and hot extremes' were analyzed. The duration of the longest dry spell in the period 2070-2099 over Europe is likely to

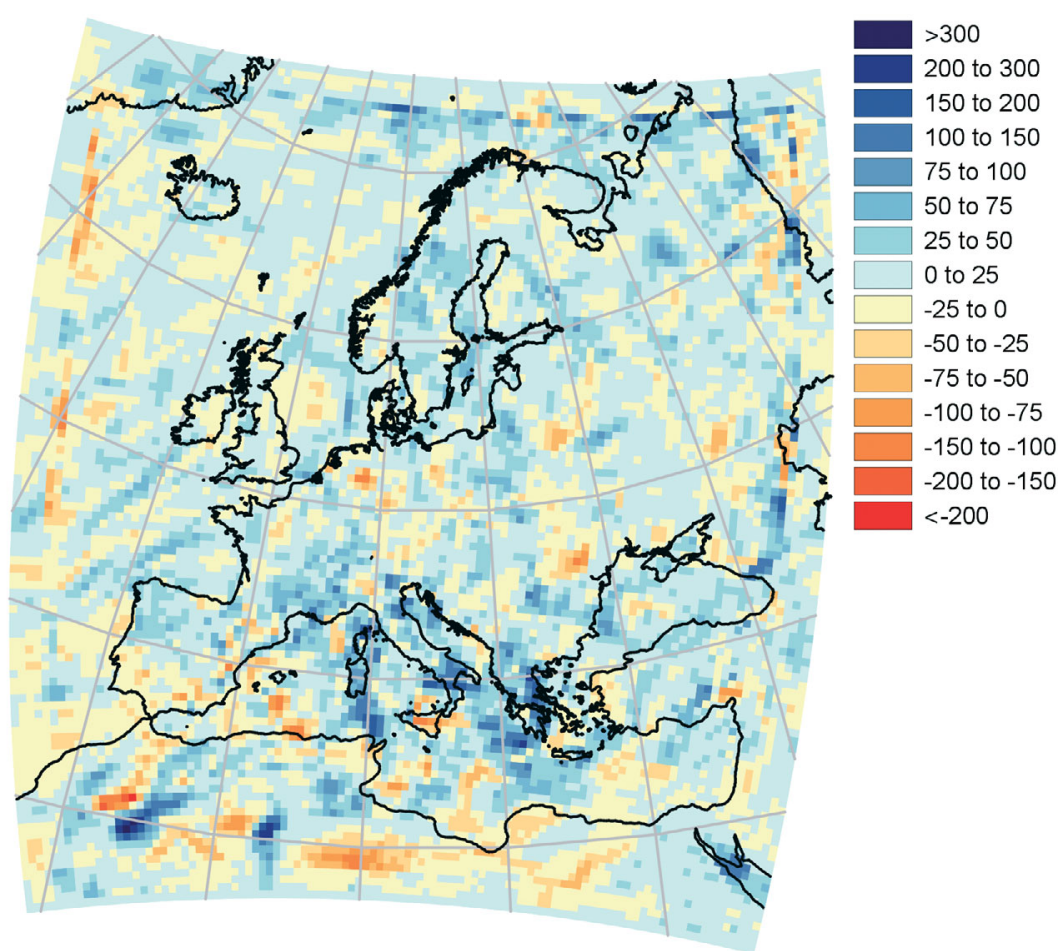

Fig. 2. Difference in annual maximum daily precipitation (mm) over Europe between the control period (1961-1990) and future projection (2070-2099) (HadRM3-P, SRES A2 scenario)

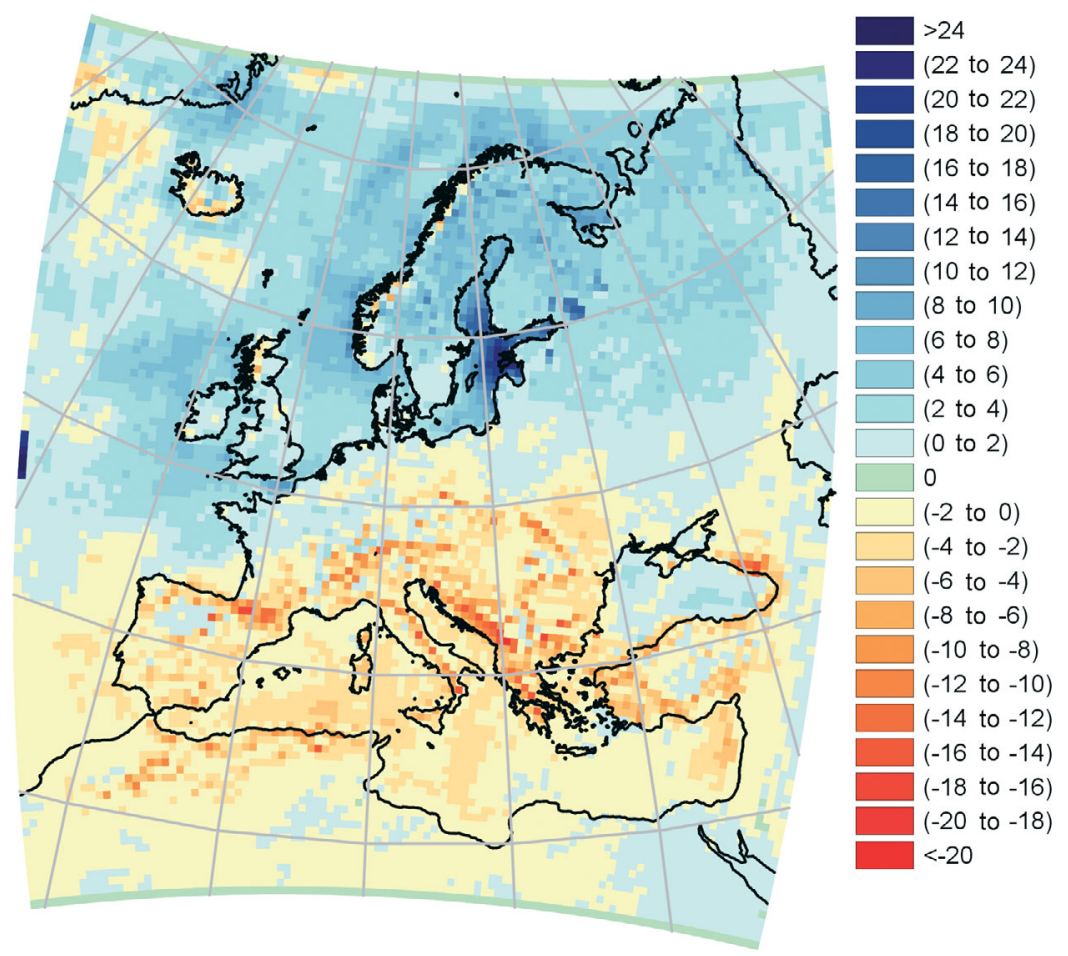

Fig. 3. Comparison of no. of days with precipitation $>10 \mathrm{~mm}$ between the control period (1961-1990) and future projection (2070-2099) (HadRM3-P, SRES A2 scenario) 

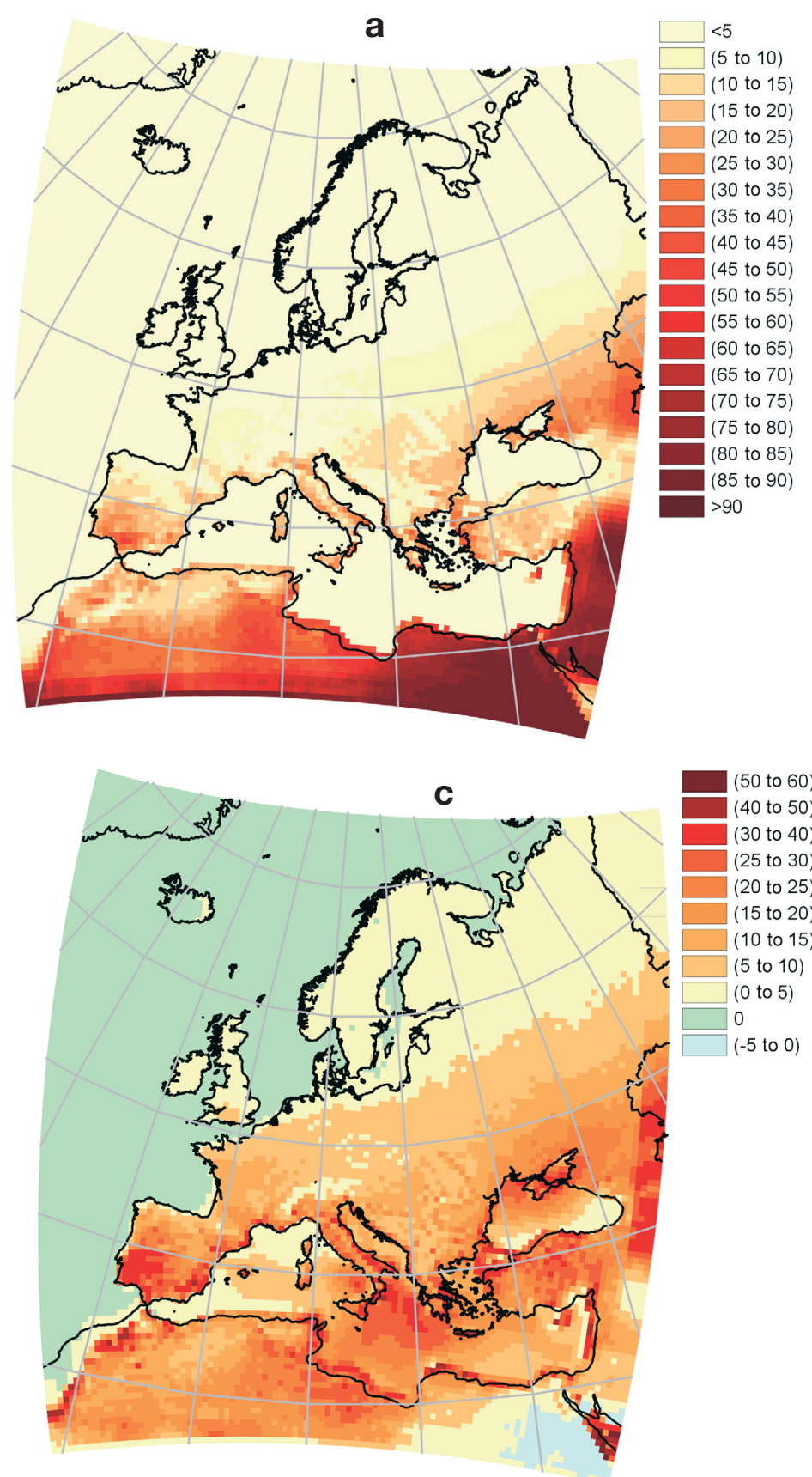

be considerably longer than in 1961-1990. Bivariate analysis of longest hot and dry spells (with several thresholds of 'hot' and 'dry') shows considerable changes. The areas already affected by water stress in the present climate (e.g. southern Europe) are expected to experience even more severe conditions in the future, and the modelled changes are statistically significant.

The maps presented in Figs. 4 \& 5 display mean values of annual indices over 3 HadRM3-P model

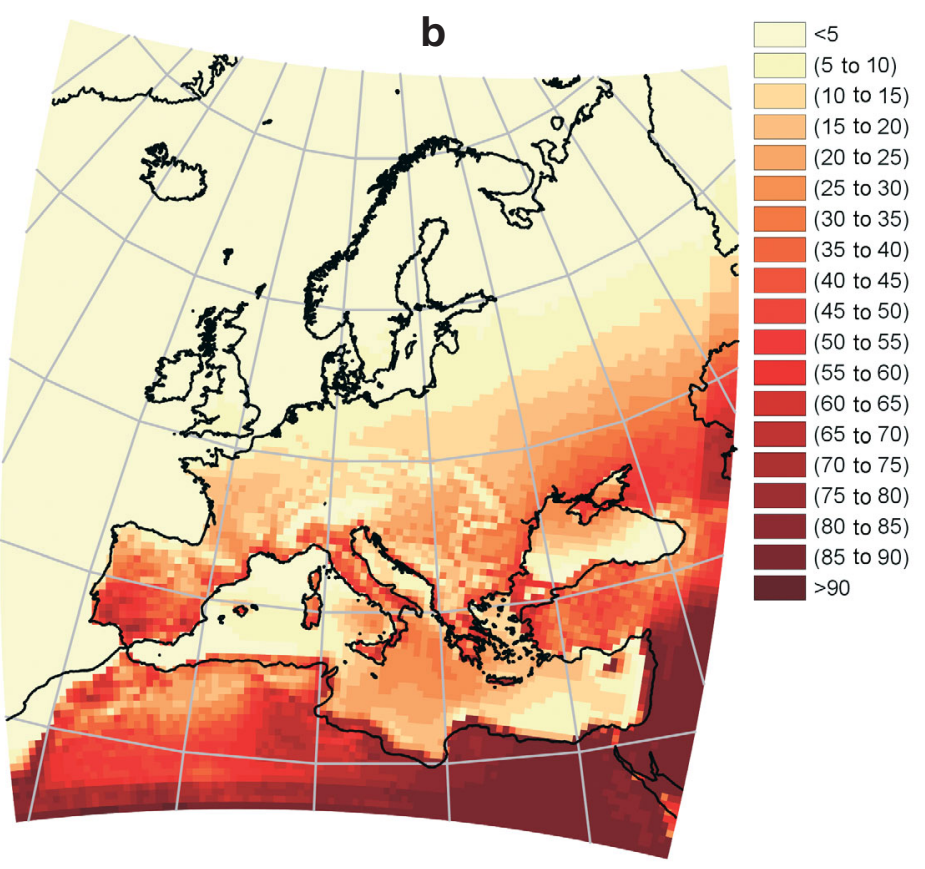

Fig. 4. Mean duration (days) of the longest 'dry and hot' spell $\left(\mathrm{T}_{\max } \geq 30^{\circ} \mathrm{C}\right.$, precipitation $\leq 0.5 \mathrm{~mm}$ ) according to HadRM3-P SRES A2 scenario: (a) 1961-1990;

(b) 2070-2099; (c) the change between periods represented in (a) and (b)

experiments (for the SRES A2 scenario). Changes were clearly visible and statistically significant for almost the entire European continent, in all cases studied and in all 3 model experiments (for details see Pinskwar et al. 2004).

Fig. 4 illustrates results obtained for the longest dry and hot period (number of consecutive hot and dry days) in summer for the 2 periods 1961-1990 and 2070-2099. The $30 \mathrm{yr}$ mean of the longest spell with $\mathrm{T}_{\text {max }} \geq 30^{\circ} \mathrm{C}, \mathrm{P} \leq 0.5 \mathrm{~mm}$ increases over most of Europe, most notably over the southern areas. A marked difference, with a considerable (and highly significant, $\mathrm{p} \leq 0.01$ level) increase in the length of the maximum hot and dry period is projected over the Mediterranean and Black Sea. Results for other thresholds of maximum temperature and precipitation can be found in Pínskwar et al. (2004).

Fig. 5 presents results obtained for the duration of the longest dry period (number of consecutive dry days with $\mathrm{P} \leq 0.5 \mathrm{~mm}$ ) in summer between the two $30 \mathrm{yr}$ periods (1961-1990 and 2070-2099), based on HadRM3-P for the SRES A2 scenario. It shows a uniform increase in the duration of the longest dry period for the entire southern part of Europe and much of central Europe. Changes had high levels of signifi- 
cance $(\mathrm{P} \leq 0.1)$ over nearly all of Spain, Portugal, France, and Italy. See Pińskwar et al. (2004) for more detailed discussion and results for different combinations of maximum temperature/precipitation thresholds.

The changes for the Poznan grid cell (Table 1) are not as strong as for southern Europe, but are still statistically significant. The mean duration of hot and dry periods for the Poznań grid cell is projected to increase considerably between the control period 1961-1990 and the future projection period 2070-2099. For example, the mean length of dry and hot periods at $\mathrm{T}_{\max } \geq 30^{\circ} \mathrm{C}$ and $\mathrm{P} \leq 0.5 \mathrm{~mm}$ is projected to increase by 6 d, i.e. by $125 \%$.

\section{CONCLUDING REMARKS}

Flood damage has clearly increased over the last decades, and a part of this rising trend is linked to socio-economic factors, such as population growth and accumulation of increasing wealth in flood-prone areas. According to Pielke \& Downton (2000), climate has played an important but by no means determining role in the growth of damaging floods in the United States in recent decades. The effect from increasing human development of flood plains (a consequence of population growth and wealth increase) was found to be much higher than that from increased precipitation (Pielke \& Downton 2000).

In many areas in Europe, intense precipitation and related river flood risk may increase in the future. However, floods are a complex process, and thus blanket statements on the direction of change in flood are liable to be inaccurate. The different mechanisms triggering inundations are affected in different ways by climate change. Increase in intense precipitation in a warming Europe is plausible, as shown in several analyses of observed data and in the projections in this study, and is likely to lead to a rise in flood hazards. On the other hand, snowmelt and ice-jam floods are likely to decrease in many areas with increasing temperature; therefore, in regions where floods can be caused by several possible mechanisms, the net effect of climate change on flood risk is not immediately clear (Kundzewicz et al. in press). Flood risk is controlled by a number of non-climatic factors such as population growth, increase in
Table 1. Mean duration of hot and dry periods at different precipitation thresholds and for $\mathrm{T}_{\max } \geq 25$ or $\geq 30^{\circ} \mathrm{C}$ for the Poznan grid cell (HadRM3-P, SRES A2 scenario)

\begin{tabular}{|lccc|}
\hline & $\begin{array}{c}\text { Precipitation } \\
\text { threshold } \\
(\mathrm{mm})\end{array}$ & \multicolumn{2}{c|}{$\begin{array}{c}\text { Mean duration of hot and } \\
\text { dry period for all } \\
3 \text { model runs (d) } \\
\geq 25^{\circ} \mathrm{C}\end{array}$} \\
& & 5.7 & 3.5 \\
\hline Past (1961-1990) & 0 & 9.9 & 7.4 \\
Future (2070-2100) & & 4.2 & 3.9 \\
Difference (Future- Past) & & 6.7 & 4.0 \\
Past (1961-1990) & $\leq 0.1$ & 12.1 & 8.7 \\
Future (2070-2100) & & 5.4 & 4.7 \\
Difference (Future- Past) & & 8.4 & 4.8 \\
Past (1961-1990) & $\leq 0.5$ & 15.3 & 10.8 \\
Future (2070-2100) & & 6.9 & 6.0 \\
Difference (Future- Past) & & & \\
\hline
\end{tabular}


Conclusions drawn from analyses reported in this study indicate that 'dry and hot' extremes may become more severe in the future climate for most of Europe. The duration of the longest dry spell in the period 2070-2099 over grid cells of the European continent is expected to be considerably longer than in the control period 1961-1990. The increase in length of hot-anddry spells is particularly strong and statistically significant for southern Europe. Areas already affected by droughts (due to low precipitation and high temperature extremes in the present climate, e.g. southern Europe) are expected to experience even more severe conditions in the future, with adverse consequences for such sectors as agriculture (risk of poor harvest), water supply (risk of water deficit, where availability cannot meet demand of all sectors, including industry, energy, and municipal water supply), and forestry (increased wild fire risk). Increased ecosystem stress and water quality problems are also expected.

There is still a great deal of uncertainty regarding likely climate change impacts on water resources. This is partly due to differences between estimates of precipitation in different climate models and for different emission scenarios. The direction of projected change of hydrological processes is consistent across different models and scenarios for some, but certainly not all, areas. The scale of the mis-match between coarseresolution climate models and the hydrological (catchment) scale is another source of uncertainty.

Climatic impacts on water resources depend not only on changes in the characteristics of precipitation, streamflow and aquifer recharge, but also on the management of the water resource system (and therein organizational and institutional aspects), and the capacity of this system to adapt. Climate change is just one of several pressures that will potentially impact on water resources. Other pressures include overexploitation of the resource, general environmental degradation, and water quality deterioration. Climate change may challenge existing water resource management practices by contributing to additional uncertainty, but non-climatic changes may have a greater impact in particular areas (cf. Krysanova et al. in press). In view of multiple stresses, including adverse climate change impacts on water resources, improvement in efficiency of water use (possibly via integrated water management) is essential.

Acknowledgements. A major part of this research was carried out under the MICE (Modelling the Impact of Climate Extremes) Project financed by the European Commission under the 5th Framework Programme. Climate-model data, produced by the Hadley Centre, have been provided to MICE by the LINK Project, funded by the UK Department of the Environment, Food and Rural Affairs. A part of this research was performed within the ENSEMBLES (Ensembles-Based Predictions of Climate Changes and their Impacts) Project financed by the European Commission under the 6th Framework Programme. M.R. was partly supported by the Foundation for Polish Science. Constructive remarks of 3 anonymous referees, which helped the authors to improve the paper, are gratefully acknowledged.

\section{LITERATURE CITED}

Alpert P, Ben-Gai T, Baharad A, Benjamini Y and 8 others (2002) The paradoxical increase of Mediterranean extreme daily rainfall in spite of decrease in total values. Geophys Res Lett 29:31-1-31-4, doi:10.1029/2001GL013554

Arnell N, Liu C (2001) Hydrology and water resources. In: McCarthy JJ, Canziani OF, Leary NA, Dokken DJ, White KS (eds) Climate change 2001: impacts, adaptation and vulnerability. Contribution of the Working Group II to the Third Assessment Report of the Intergovernmental Panel on Climate Change. Cambridge University Press, Cambridge, p 191-233

Brunetti M, Bufoni L, Mangianti F, Maugeri M, Nanni T (2004) Temperature, precipitation and extreme events during the last century in Italy. Global Planet Change 40:141-149

Christensen JH, Christensen OB (2003) Severe summertime flooding in Europe. Nature 421:805

Frei C, Schär C (2001) Detection probability of trends in rare events: theory and application to heavy precipitation in the Alpine region. J Clim 14:1568-1584

Graczyk D, Kundzewicz ZW (2002) Charakterystyki ekstremów na polskich stacjach objętych Europejskim Archiwum Klimatycznym. In: Kundzewicz ZW, Radziejewski M (eds) Detekcja zmian klimatu i procesów hydrologicznych. Sorus, Poznán, p 115-124

Houghton JT, Ding Y, Griggs DJ, Noguer M, van der Linden PJ, Dai X, Maskell K, Johnson CA (2001) Climate change 2001: the scientific basis. Contribution of Working Group I to the Third Assessment Report of the Intergovernmental Panel on Climate Change. Cambridge University Press, Cambridge

Klein Tank AMG, Koennen GP (2003) Trends in indices of daily temperature and precipitation extremes in Europe, 1946-99. J Clim 16:3665-3680

Krysanova V, Kundzewicz ZW, Pińskwar I, Habeck A, Hattermann F (in press) Regional socio-economic and environmental changes and their impacts on water resourcesexample of Odra and Elbe basins. Water Resour Manage

Kundzewicz ZW, Ulbrich U, Brücher T, Leckenbusch G, Menzel L, Przymusińska I, Radziejewski M, Szwed M (in press) Summer floods in Central Europe-climate change track? Nat Hazards

McCarthy JJ, Canziani OF, Leary NA, Dokken DJ, White KS (2001) Climate change 2001: impacts, adaptation and vulnerability. Contribution of Working Group II to the Third Assessment Report of the Intergovernmental Panel on Climate Change. Cambridge University Press, Cambridge

Nakicenovic N, Alcamo J, Davis G, de Vries B and 24 others (2000) IPCC special report on emissions scenarios. Cambridge University Press, Cambridge

New M, Hulme M, Jones PD (1999) Representing twentieth century space-time climate variability. Part I: development of a 1961-90 mean monthly terrestrial climatology. J Clim 12:829-856 
Parry ML (2000) Assessment of potential effects and adaptations for climate change in Europe: the Europe ACACIA Project. University of East Anglia, Norwich

Pielke RA Jr, Downton MW (2000) Precipitation and damaging floods: trends in the United States, 1932-1997. J Clim 13:3625-3637

Pinskwar I, Radziejewski M, Kundzewicz ZW (2004) Dry and warm spells in Europe-climate model projections. Pap

Submitted: April 6, 2005; Accepted: February 25, 2006
Global Change 11:33-42

Schmidli J, Frei CH (2005) Trends of heavy precipitation and wet and dry spells in Switzerland during the 20th century. Int J Climatol 25:753-771

Zolina O, Kapala A, Simmer C, Gulev SK (2004) Analysis of extreme precipitation over Europe from different reanalyses: a comparative assessment. Global Planet Change 44:129-161

Proofs received from author(s): May 29, 2006 